\title{
O nowej duchowości - próba opisu zjawiska
}

\begin{abstract}
Abstrakt
Wielu socjologów stawia pytanie, czy nie należy już mówić o nowej subdyscyplinie socjologicznej, mianowicie o socjologii duchowości, która analizuje nowe formy duchowości w kontekście przemian społeczeństw współczesnych. Część socjologów uznaje nowe formy duchowości za przejaw powrotu sacrum czy odmiany nowej religijności. Inni skłonni są je traktować jako symptom sekularyzacji i dekadencji religii. Jeszcze inni są skłonni uznawać tzw. alternatywną duchowość za ważny megatrend społeczno-kulturowy, zwiastujący „powrót religii”. W nawiązaniu do tych dyskusji autor stawia pytanie o relacje między religijnością i duchowością, analizuje zjawiska tzw. nowej duchowości we współczesnym świecie i w końcu próbuje zdefiniować nową duchowość jako fenomen niezależny od religii. Nowa duchowość kształtuje się poza instytucjonalnymi wymiarami religii, niekiedy w opozycji do niej, w kontekście ponowoczesności.
\end{abstract}

Słowa kluczowe: religijność, nowa duchowość, sekularyzacja, desekularyzacja, ponowoczesność.

\section{On New Spirituality - An Attempt to Describe the Phenomenon}

\begin{abstract}
Many sociologists pose the question whether we should be talking about a new sociological sub-discipline, namely, the sociology of spirituality, which analyses new forms of spirituality in the context of the transformation of modern societies. Some sociologists consider new forms of spirituality as a sign of the return of the sacred, or a new kind of religiosity. Others tend to see them as a symptom of the secularization and decadence of religion. Still others are inclined to regard the
\end{abstract}

\footnotetext{
* Wyższa Szkoła Nauk Społecznych z siedzibą w Lublinie.

Artykuł otrzymano: 19.10.2020; akceptacja: 13.01.2021.
} 
so-called alternative spirituality as an important sociocultural megatrend heralding the "return of religion". In reference to these discussions, the author poses a question about the relationship between religiosity and spirituality, and analyses the phenomena of the so-called new spirituality in the contemporary world. He further tries to define the new spirituality as a phenomenon independent of religion. The new spirituality is formed outside of the institutional dimensions of religion, sometimes in opposition to it, in the context of post-modernity.

Keywords: religiosity, new spirituality, secularization, desecularization, postmodernity.

\section{Wstęp}

Badania nad duchowością prowadzone w ramach socjologii prowokują do stawiania pytań o jej źródła, formy i kształty urzeczywistniania się, o jej oddziaływanie na różne dziedziny życia społecznego. Wielu badaczy duchowości nie troszczy się o zdefiniowanie zjawiska lub nawet świadomie tego unika, wielu nie chce poprzez ścisłe definicje zawężać pola badawczego nad wciąż nowymi przejawami duchowości kształtującej się poza ramami religijności zinstytucjonalizowanej, aż po swoistą duchowość agnostyczną czy duchowość bez Boga (duchowość rozproszona, rozmyta, sfragmentaryzowana, płynna, pozakościelna, pozawyznaniowa, laicka, niereligijna, nieostentacyjna, ekspresyjna, immanentna, nieugruntowana kościelnie) (Mariański, Wargacki 2016; Wargacki 2016; Mariański 2010b: 195-242).

Zjawiska nowej duchowości są niezwykle dynamiczne i względne, trochę w swoim trwaniu podobne do mgły czy rosy porannej, która prędko znika. W adhortacji apostolskiej Evangelii gaudium Papież Franciszek napisał:

W innych kręgach naszych społeczeństw wzrasta zachwyt różnymi formami „duchowości dobrobytu” bez wspólnoty, dla „teologii pomyślności” bez braterskich zobowiązań, albo do subiektywnych doświadczeń bezosobowych, sprowadzających się do immanentnego poszukiwania wewnętrznego (Ojciec Święty Franciszek 2013).

Nowa duchowość kształtuje się poza instytucjonalnymi wymiarami religii, często nawet w opozycji do nich.

Nowe poszukiwania duchowości, swoisty powrót sacrum, o czym mówią socjologowie, oznacza z jednej strony odejście od tradycyjnego, religijno-kościelnego rozumienia sensu z jego odniesieniami do wielkiej Transcendencji (doświadczenia wertykalne), z drugiej strony jest zaakcentowaniem życia jako wartości samej w sobie, będącym źródłem poznawania siebie i rozwoju osobistego (doświadczenia horyzontalne).

Dla fenomenu duchowości właściwe jest przekonanie o istnieniu jakiegoś nadnaturalnego wymiaru, z którym ludzka jaźń może się połączyć poprzez indywidual- 
ny duchowy wysiłek, samotne wyciszenie i medytację. Kontakt z pozazmysłową rzeczywistością miewa często zadziwiająco pozytywne skutki, np. pogłębia wrażliwość, wzbudza w człowieku energie samoleczące i daje poczucie zadomowienia we wszechświecie oraz bycia ważną częścią uniwersum (Mielicka-Pawłowska 2017a; Zduniak 2016).

O ile dawniej religijność i duchowość były definiowane do pewnego stopnia komplementarnie, a instytucje religijno-kościelne określały granice manifestowania się duchowości oraz jej formy i kształty, w jakich ona mogła się pojawiać, to obecnie obydwie rzeczywistości rozchodzą się, a nowa duchowość nie odwołuje się już do jakichkolwiek doktryn religijnych. Kształtuje się ona poniekąd we wnętrzu człowieka, na miarę jego indywidualnych potrzeb. Termin „nowa duchowość” jest czymś mglistym i wieloznacznym, będącym czymś obok lub nawet w opozycji do religijności instytucjonalnej (Mariański 2018; Libiszowska-Żółtkowska 2018; Mielicka-Pawłowska 2018). Mirosława Grabowska mówi o nowej duchowości jako „późnym dziecku przekwitającej teorii sekularyzacji” (Grabowska 2018: 14), a Zygmunt Bauman w rozmowie z Peterem Haffnerem stwierdził: „To, co przeżywamy w zachodnim świecie, to nie powrót religii, lecz duchowości. Ludzie nie wracają do Kościołów, lecz do czegoś wewnętrznego, stojącego ponad codziennym życiem, z dala od codziennego trudu" (Haffner 2019: 166). Niektórzy badacze społeczni stosują określenie „duchowość ponowoczesna” (Niedałtowski 2008; Misztal 2017).

Duchowość ta może kłaść nacisk na immanentnego Boga, podkreślać rolę doznań i duchowych ćwiczeń; troszczyć się i szanować ciało; bywa wrażliwa na różnice płci; często wykazuje wrażliwość ekologiczną, nastawiając się na współpracę z innymi istotami żywymi, gdyż Ziemia to nasz wspólny dom. Doświadczenie sacrum jest niezmiernie ważne, gdyż budzi w nas coś wykraczającego poza codzienną rzeczywistość (Wargacki 2011: 4).

W nurtach nowej duchowości oferuje się ezoteryczne sposoby osiągania natychmiastowej satysfakcji, automatycznej asertywności, wyższej duchowości, zdrowia, sukcesu, jasności umysłu, rozwoju potencjału ludzkiego. To, co ostateczne, należy do tego świata, a poziom Transcendencji ulega obniżeniu (odejście od Wielkich Transcendencji w stronę małych lub pośrednich transcendencji w ujęciu Thomasa Luckmanna) (Dobbelaere 2008: 256). Ci, którzy w swoich Kościołach nie znajdują źródeł motywujących ich ideowo, uciekają się do ezoteryzmu, New Age, sekt i różnych nowych form duchowości pokrewnych religii lub nawet całkowicie od niej odmiennych (Chmielewski 2017-2018; Ferdek 2017; Machniak 1999).

Niekiedy twierdzi się, że ci, którzy czują się rozczarowani swoją religią, odczuwają potrzebę poszukiwania i odkrywania czegoś, co oni sami albo badacze życia religijnego nazywają duchowością. Nowa duchowość nie jest ani duchowością chrześcijańską, ani duchowością religijną. Odnosi się ona jednak do tych, którzy 
identyfikują się jako osoby duchowe, chociaż niereligijne. Niektórzy stosują pojęcie duchowości w znaczeniu odrzucenia religii i religijności. W tym kontekście uzasadnione jest rozróżnienie duchowości religijnej i niereligijnej (Pawluczuk 2016; Bańka 2012; Chmielewski 2013).

$\mathrm{Z}$ analizy różnych koncepcji socjologicznych duchowości wynika, że nowa duchowość ma charakter zdecydowanie pluralistyczny. Obejmuje ona nie tylko poszukiwania ezoteryczne (od astrologii po okultyzm), ale także niektóre treści pochodzące z religii azjatyckich i przedchrześcijańskich. Światopogląd ludzi poszukujących nowych form duchowości jest w znacznym stopniu synkretyczny i przypadkowy normatywnie. Ludzie pragną przede wszystkim otrzymać pomoc w konkretnych - najczęściej trudnych - sytuacjach życiowych, rozszerzyć swoją świadomość, wyjść poza nużącą i bezsensowną codzienność. Wielu z nich usiłuje odnaleźć w nowych formach duchowości ważny sens swojego życia. Funkcjonują rozmaite ośrodki medytacyjne i oferty cudownych uzdrowień, warsztaty rozwoju osobowego i duchowego, coaching, filmy o tematyce duchowości, muzyka relaksacyjna i medytacyjna. Mówi się nawet o „zwrocie ku duchowości” lub o „dynamice duchowości”, o „rewolucji duchowości”, o ponowoczesnych formach duchowości poza Kościołami i religiami, o duchowości religijnej i duchowości niereligijnej, o duchowości dialogu międzyreligijnego, o duchowości integralnej itp. (Sztaba 2014; Solecki, Borda 2018: 17-65; Sakowicz 2002).

Nowa duchowość o charakterze eklektycznym i efemerycznym wypiera tradycyjną, kościelnie zorientowaną religijność lub rozwija się niezależnie od niej. Jest ona

zorientowana nie ku transcendencji, jak w tradycyjnych religiach, ale ku wnętrzu człowieka, pierwiastków boskich poszukuje się w tej formie w samym sobie, często $\mathrm{w}$ powiązaniu z założeniem samorozwoju, odkrywania prawdy o sobie i świecie, niejednokrotnie wmontowuje się w te poszukiwania nieortodoksyjne nurty w nauce (Borowik 2016: 12-13).

Pojawiające się nowe nurty duchowości, zwłaszcza duchowości niereligijnej, sprawiają, że w naukach społecznych coraz częściej mówi się o socjologii duchowości (Kutyło 2012a, b). Konstatacja Andrzeja Kojdera: „Duchowość - problem za trudny dla polskich socjologów" (Kojder 2009: 93) przestaje powoli być aktualna. Literatura socjologiczna, psychologiczna, pedagogiczna, kulturoznawcza, filozoficzna i teologiczna narasta $\mathrm{w}$ bardzo szybkim tempie. Wielu badaczy społecznych nie troszczy się o skonstruowanie ścisłej definicji nowej duchowości, a niektórzy uznają taką definicję za niepotrzebną. Wystarczy tylko określenie przedmiotu badań. W niniejszym artykule podejmujemy próbę określenia zjawiska nowej duchowości: nowa duchowość jako fenomen społeczno-kulturowy, nowa duchowość w kontekście ponowoczesności, cechy charakterystyczne nowej duchowości. 


\section{Nowa duchowość jako fenomen społeczno-kulturowy}

Duchowość pojawia się coraz częściej w rozważaniach socjologicznych, tu jednak na ogół z przymiotnikiem „nowa”. Współcześnie termin „nowa duchowość” odgrywa $\mathrm{w}$ badaniach socjologicznych znaczącą rolę, zajmuje on powoli miejsce religii, religijności czy wiary, a nawet sacrum. Przez nową duchowość rozumie się bardzo rozmaite oferty sensu i interpretacji życia, począwszy od ezoteryki, poprzez rozmaite formy uzdrowień, aż do różnego rodzaju zachodnich adaptacji buddyzmu. Coraz mniej jest tu odniesień do wyzwań religijnych, więcej do Siły Wyższej, Kosmosu, Natury, Uniwersum, aż po brak odniesień do jakichkolwiek Transcendencji. Dzisiejszy człowiek, poszukując sensu życia, szuka siebie, w całym pluralizmie ofert, które są mu dostępne, ale równocześnie dokonuje swoistej samotranscendencji, wykraczając - poprzez uznawane wartości - poza własne „ja”, w kierunku jakiejś „wyższej siły".

Najogólniej rzecz biorąc, duchowość łączy się z pewnego rodzaju doświadczeniami o charakterze osobistym (przeżywanie, doznawanie), niekiedy z czymś nadzwyczajnym, jako coś przeżywane bezpośrednio, bez pośrednictwa Kościoła (nie z „drugiej ręki”). Według Dominiki Motak o nowej duchowości

można mówić wtedy, gdy staje się ona „wiarą dla” jednostki - gdy jest tworzona przez jednostkę dla niej samej, w odpowiedzi na jej własne „duchowe potrzeby”. Materią, z której uszyta jest ta „duchowość na miarę”, jest przede wszystkim „przeżycie” (doświadczenie, emocja, uczucie). Wiąże się to ze „zwrotem ku doświadczeniu”, konstatowanym już przez pierwszych teoretyków nowoczesności (Motak 2010: 216).

Nowa duchowość nie sytuuje się w obrębie Kościołów chrześcijańskich, ale uobecnia się przede wszystkim w sferze pozakościelnej i przybiera nowe zewnętrzne formy (nie jest niewidzialna), inne niż w tradycyjnych religiach (Chmielewski 2020). Zaciera się granica miedzy tym, co sakralne i świeckie, transcendentne i immanentne. Różne przejawy duchowości można obserwować zarówno w „małych światach" jednostek (np. traumatyczne przeżycia związane ze śmiercią), jak i w wielkich zgromadzeniach czy tragicznych wydarzeniach (np. eventy religijne, wielkie koncerty muzyczne, zawody sportowe, spotkania z Papieżem, trzęsienia ziemi i inne katastrofy). Zaangażowanie się w wielkie wydarzenia i uroczystości o charakterze religijnym (eventy) nie zawsze, a może nawet na ogół, nie prowadzi do nawiązania kontaktów z własną wspólnotą parafialną czy wyznaniową. Stwarzają one młodzieży możliwości doświadczenia wspólnotowości jako przeżyć duchowych. Niekiedy warunkują zmiany w życiu codziennym. Alternatywne formy religijności i nowa duchowość oznaczają często samodzielne poszukiwania człowieka, prowadzące go do zamykania się w obrębie własnego subiektywnego świata duchowego (Zduniak 2018; Stachowska 2019a, b). 
Problemy badawcze i metodologiczne związane z nową duchowością Halina Mielicka-Pawłowska ujmuje syntetycznie w następujący sposób:

Po pierwsze: religijność i duchowość są zjawiskami społecznymi, które mogą stać się faktami, ale mogą też być tylko „mitem”, a więc „miękką" empirycznie kategorią tego, co „zjawia się” w prowadzonych przez socjologów badaniach. Po drugie: religijność i duchowość, jako fakty społeczne, stanowią przedmiot badań socjologów religii, co oznacza, że konieczne jest przestrzeganie zasady rygoryzmu metodologicznego w stosunku do przedmiotu badań teologicznych i psychologicznych. Po trzecie: stosowane przez socjologów narzędzia i techniki badawcze są skuteczne, gdyż pozwalają uchwycić nowe zjawiska społeczne (...). Po czwarte: analizowanie zjawisk wskazujących istnienie procesu społecznego in statu nascendi, pozwala na dokonanie weryfikacji teorii, które już nie wystarczają, a więc są zawodne eksplanacyjne (Mielicka-Pawłowska 2019: 13).

W badaniach empirycznych konstruuje się już oddzielnie skalę religijności i skalę duchowości oraz stawia się pytania, jak bardzo respondenci są religijni i jak bardzo są uduchowieni (McGuire 2012: 106-107; Sakowicz 2001). Coraz wyraźniej uświadamiamy sobie, że duchowość może istnieć także poza religią.

\begin{abstract}
Zdajemy sobie jednak sprawę z tego, że takie osoby, które nie identyfikują się z żadną tak pojętą religią, a nawet ją odrzucają, mają jednak potrzebę przekraczania granic swoich potrzeb biologicznych, psychicznych czy intelektualnych. Słusznie zatem możemy mówić nie tylko o potrzebie religijnej, ale także o potrzebie duchowości, to znaczy o potrzebie autotranscendencji (Chmielewski 2005: 10).
\end{abstract}

W ujęciu Zbigniewa Paska i Katarzyny Skowronek duchowość ujawnia się jako stała cecha kulturotwórczej postawy człowieka, posiada uniwersalny, ponadreligijny charakter. Określa ona dążenia człowieka do rozwoju i zmiany jego aktualnego stanu, zarówno w wymiarze indywidualnym, jak i społecznym, sytuuje się w różnych dziedzinach kultury, z którą ściśle jest związana („nie ma kultury bez duchowości”). Duchowość w szerokim znaczeniu obejmuje idee i działania występujące w obrębie religii, jak i również poza nią. Jeżeli duchowość uznamy za stały element kultury, to nowa duchowość jest istotnym nurtem kultury współczesnej (Pasek, Skowronek 2011; Skowronek, Pasek 2013).

Według Paska współcześnie

duchowość oznacza dokonywane różnymi środkami dążenia człowieka do przekraczania własnej kondycji. Przede wszystkim oznacza transgresję doczesności materialnej i przemijającej. Proces ten dokonuje się w imię wartości wyższych, odbieranych jako pozytywne, dobre (...). Mogą to być 
zarówno wartości religijne, jak i etyczne, estetyczne czy inne, realizowane zupełnie poza sferą religii (Pasek 2008: 23).

Nowa duchowość - twierdzi Pasek - obejmuje próby odnalezienia czy nadania głębszego sensu własnej pracy człowieka nad swoją świadomością (samorealizacja, podnoszenie swojej świadomości na wyższy poziom). W nowej duchowości człowiek kształtuje indywidualnie swój rozwój przy pomocy mistrzów duchowych, ale nie w wyniku danej przez Boga siły nadprzyrodzonej, łaski (Chmielewski 2016; Pasek 2010).

Socjologowie niemieccy nie używają pojęcia nowa duchowość, lecz po prostu duchowość (Spiritualität) (Knoblauch 2005, 2006, 2008, 2009; Dienberg, Eggensperger, Engel 2013). Cechami współczesnej duchowości są: a) zdecydowana orientacja na subiektywne doświadczenie; b) źródłami jej są alternatywne religijności odróżniające się od dotychczasowych tradycji religijnych, pochodzące ze wschodnich, archaicznych, okultystycznych, mistycznych tradycji; c) dystans do dogmatyki religijnej wielkich organizacji kościelnych i swoisty antyinstytucjonalizm; d) zaakcentowanie religijnej autonomii jednostki i związany z tym wyraźny indywidualizm światopoglądowy; e) orientacja na doświadczenie umożliwia podejście całościowe do życia, które pozwala zrozumieć i wyjaśnić funkcjonalne zróżnicowania społeczeństwa; f) dla samego działającego duchowość staje się alternatywnym pojęciem do religii. Według Huberta Knoblaucha duchowość może być rozumiana jako rozszerzenie tego, co Thomas Luckmann nazywał „społeczną formą sprywatyzowanej religii" (Knoblauch 2005: 123).

Knoblauch wprowadza na określenie tych nowych zjawisk termin „popularna religia” (Populäre Religion), traktując duchowość jako część kultury popularnej (ale nie ludowej). Termin ten obejmuje znacznie więcej zjawisk niż dotychczas stosowany w socjologicznej literaturze niemieckiej termin „pozakościelna religijnośc” (außerkirchliche Religiosität), który był odnoszony najczęściej do różnych zjawisk parareligijnych (wiara w UFO, New Age, okultyzm, ezoteryzm i inne). Duchowość (Spiritualität) odcina się od dogmatycznej religii, nie tylko od wielkich tradycyjnych religii, ale i od mniejszych ugrupowań religijnych (np. sekt). Jest ona rodzajem osobowego doświadczenia dostępnego dla wszystkich, nie tylko dla ekspertów czy wirtuozów religijnych. Każdy może nawiązać kontakt z bóstwem, bez pośrednictwa Kościoła (duchowość alternatywna). Niekiedy duchowość przejawia się w takich zewnętrznych formach jak prorokowanie, mowa języków, nawrócenia, uzdrowienia itp. Dymensja doświadczenia duchowego zastępuje dogmatyczny i instytucjonalny wymiar religii, nie tyle zmierza ona do zmiany moralności człowieka, ile raczej jest dowodem istnienia motywacyjnych sił i energii w człowieku (Knoblauch 2006, 2008).

Knoblauch wyróżnia nowoczesną duchowość chrześcijańską i alternatywną religijną duchowość (alternativ-religiöse Spiritualität). Tę drugą charakteryzują następujące cechy: 
a) Alternatywna duchowość jest zdystansowana wobec dogmatyki kościelnej, docenia się w niej wymiar doświadczenia i rolę podmiotu, w mniejszym stopniu odniesienia społeczne. Religia wprost przeciwnie, akcentuje specyficzne, instytucjonalnie uznawane treści, wyrażające się w dogmatach (prawdy wiary), w liturgii, w uprawomocnieniu wybranych osób (np. duchowni). Duchowość bazuje na doświadczeniu subiektywnym, które przesuwa podstawę wiary do własnego „ja”. Dlatego też wykazuje ona wiele podobieństw z dążeniem do autentyczności związanej z nowoczesnym indywidualizmem. Nie wyklucza ta cecha przynależności do małych wspólnot (np. wspólnoty zaufania), a niekiedy i wielkich wspólnot (np. religijne eventy).

b) Dystans wobec wielkich religijnych form organizacyjnych, ale nie na kształt niewidzialnego Kościoła powszechnego (uniwersalnego). W naszym kręgu kulturowym duchowość jawi się jakby obok religii (w sensie semantycznym i strukturalnym). Nowe formy duchowych doświadczeń są nośnikami resakralizacji i respirytualizacji, a poprzez swoją orientację subiektywistyczną dobrze korespondują z indywidualistycznymi tendencjami ponowoczesności.

c) Jest ruchem ukierunkowanym na „całościowość”, a więc obejmuje wszystkie sfery życia (psychikę, ciało, zdrowie, relacje z innymi, a nawet politykę). Ważną rolę odgrywają tu medytacyjne praktyki, homeopatia, joga i praktyki zmierzające do różnego rodzaju uzdrowienia całości życia ludzkiego.

d) „Pole religijne” staje się poprzez duchowość poniekąd rozszerzone, a ona sama coraz częściej staje się odrębnym sektorem ludzkiego doświadczenia. Dzięki mediom i „rynkowi” staje się częścią kultury popularnej, szerokim ruchem kulturowym. Coraz częściej funkcjonuje jako rzeczywistość alternatywna, a nie - jak było dawniej - komplementarna wobec religii.

Knoblauch mówi o popularnej religii. Za pośrednictwem kultury popularnej religijne treści wychodzą poza wąski krąg instytucji kościelnych i religijnych oraz przenikają do szerszych, „świeckich” dotąd obszarów kultury. To zjawisko powoduje dowartościowanie sfery doświadczeń niecodziennych i mocniejsze akcentowanie subiektywności. Tego rodzaju procesy zwiększają do pewnego stopnia zakres religii, ale one same coraz bardziej ją marginalizują. Zjawiska duchowości popularnej wykraczają poza tę rzeczywistość, która ujawnia się w Kościołach czy w innych organizacjach religijnych. Tworzą one szerokie pole różnorodnych alternatyw dla tradycyjnego chrześcijaństwa. Wiążą się one ze zdolnością człowieka do transcendowania codziennej rzeczywistości i „przekraczania siebie” (Knoblauch 2009).

O ile zinstytucjonalizowane religie (Kościoły) organizowały i monopolizowały charyzmę religijną, to współcześnie zaznacza się jej upowszechnienie. Duchowość uzyskuje pozytywne konotacje jako wolne i kreatywne doświadczenie transcendencji lub samotranscendencji, ma charakter osobowy, pogłębiony, powiązany z własną siłą wyższą. Charles Taylor mówi o ludziach poszukujących. Poszukujący (Seekers) są to ludzie, często młodzi, którzy są zainteresowani duchowymi aspektami życia, ale bez przynależności do wielkich wspólnot religijnych (Kościoły). We 
współczesnym świecie jest wiele takich grup, ścieżek, na których można odnajdywać różne doświadczenia duchowe, niekiedy w powiązaniu z religiami Wschodu (Taylor 2012: 17).

W zsekularyzowanym świecie

ludzie odczuwają wielki głód duchowości. Ludzie szukają dróg doświadczenia duchowego. To zaś jest możliwe przez działanie i autentyczne zaangażowanie w świat. Zaangażowanie to ma być związane niezmiennie z rozpoznawaniem dobra i zła, poszukiwaniem Boga, doszukiwaniem się łaski (Kaczmarek 2006: 230).

Wielu młodych ludzi w krajach zachodnich - w znacznie mniejszym zakresie w Polsce - pytanych o ich stosunek do religii, wskazuje na odejście od religii zinstytucjonalizowanej i swój dystans wobec Kościoła, hierarchii, dogmatów wiary i kościelnych norm moralnych. Duchowość kojarzy się im z autentycznością, przeżyciem, osobową integracją i ten nowy wymiar religijności zyskuje na znaczeniu. Duchowość, która może być do pewnego stopnia uznana za religijność doświadczeniową, religijność implicite, religijność „rozproszoną”, łatwiej łączy się z sensem życia ukierunkowanym na rzeczywistość „z tego świata”. Oznacza ona w sprawach religijnych odejście od autorytetu do samostanowienia i ekspresji (nie tyle ważne jest poznanie co doznanie). Granice manifestowania się nowej duchowości oraz formy, w jakich ona się przejawia, nie są określone przez instytucje kościelne, nie jest wyznaczana przez zewnętrzne normy czy dogmaty. „Duchowi wędrowcy” czerpią treści swojej wiary z różnych tradycji religijnych i z własnego doświadczenia.

Omówione wybiórczo różne koncepcje duchowości i nowej duchowości wskazują na ich ogromną rozmaitość, nie dają się one sprowadzić do jednego wspólnego mianownika, a z pewnością nie wyczerpują wyjaśnień tego zjawiska. Termin „nowa duchowość” zawiera w sobie wiele nieprecyzyjnych znaczeń, z przewagą pozytywnych konotacji i ocen. Nie udaje się na ogół sformułować jednoznacznej definicji ani nawet podać dokładnie zakresu znaczeniowego terminu „duchowość”. Niemniej wydaje się ona przejawem szerszego trendu, czy nawet megatrendu społeczno-kulturowego, stałym elementem ponowoczesnego świata. Nie można jej traktować jako odchylenia od jakiejś „normalności”, czy czymś, co podlega dyskwalifikacji z religijnego czy moralnego punktu widzenia (Mariański 2019: 101-139; Romanowicz 2017).

Zwłaszcza zjawisko nowej duchowości nie jest łatwo opisać za pomocą współczesnych metod socjologicznych, a dotychczasowa metodologia nauk społecznych nie zawsze nadaje się do adekwatnego ujęcia tego fenomenu indywidualnego i społecznego. Jeżeli nawet nowa duchowość wymyka się ścisłemu definiowaniu, a socjolog $\mathrm{w}$ tej kwestii jest do pewnego stopnia bezradny, gdyż nie może jej zamknąć do końca w naukowych formułach, zmierzyć i wyjaśnić, to wszystko sprawia, że problematyka szeroko rozumianej duchowości staje się jeszcze bardziej 
interesująca poznawczo niż dotychczasowe badania nad zinstytucjonalizowanymi formami religii i religijności.

Religijność i duchowość zostają zdegradowane do rangi chodliwego towaru, według krytyków ma ona swoisty „status przejściowy”. Ze względu na swoją nieprecyzyjność słowo „duchowość” pojawia się w najrozmaitszych kontekstach (np. duchowość sportu, duchowość ciała, duchowość seksualności, duchowość biznesu, duchowość muzyki, duchowość internetu, duchowość w sieci, duchowość w zarządzaniu, duchowość w pracy socjalnej i inne) (Sokołowska 2012; Lowen 1994). Krytycy nowej duchowości mówią o jej negatywnych aspektach, o tzw. ciemnej stronie duchowości lub o nieokreślonym spirytualizmie (Ptaszek 2015). Dalekie to jest od postawy obiektywno-krytycznej w ocenie różnych przejawów nowej duchowości.

Nowe nurty religijności wskazują na swoisty głód duchowości w społeczeństwach zachodnioeuropejskich. 0 ile każda religia wiąże się z jakimiś formami duchowości, to dzisiaj coraz częściej ujawniają się formy duchowości bez religii. Wzrasta zainteresowanie sprawami duchowymi bez zaangażowania $w$ życie instytucji kościelnych (orientacja na sacrum bez konfesyjnego zapośredniczenia). Rozwijające się nowe formy religijności i duchowości trudno jest sprowadzić do wspólnego mianownika, różnorodne są ich interpretacje w badaniach socjologicznych. Duchowość staje się jednak ważną kategorią socjologiczną, o pozytywnym wydźwięku, ale i o niesprecyzowanych treściach. Sfera sacrum nie znika, lecz zmienia swoje miejsce, a także przybiera nowe formy i kształty. Wzrost zainteresowań duchowością i niekonwencjonalnymi formami religijności potwierdza tezę, że człowiek współczesny odczuwa wielką potrzebę poszukiwania sensu i orientacji życia, także $w$ wymiarach transcendentnych. Zwłaszcza wielkie miasta stają się środowiskiem poszukiwania sensu, są miastami z „wieloma bóstwami”, z wieloma postaciami duchowości, a nawet formami pozareligijnej duchowości ludzi, którzy odeszli od religii i Kościoła. Ateizm nie oznacza zamknięcia się na życie duchowe i rezygnację z poszukiwania wyższych wartości i sensu (Tyrała 2013; Kula 2012; Fedele 2020).

\section{Nowa duchowość w kontekście ponowoczesności}

$\mathrm{Na}$ przekór teoriom sekularyzacyjnym, w warunkach radykalnych procesów sekularyzacyjnych w Europie Zachodniej, pojawia się niespodziewanie, w wymiarach dotąd niespotykanych, dążenie do duchowości, zwane też niekiedy nową duchowością. Silne pragnienie życia duchowego jest ważnym aspektem zmian we współczesnej cywilizacji europejskiej i światowej. 0 ile dawniej duchowość była utożsamiana z religią bądź traktowana jako jeden z jej aspektów, to współcześnie jest ona ujmowana jako fenomen urzeczywistniający się poza oficjalnymi strukturami kościelnymi, a nawet jako alternatywa wobec religii czy forma sprzeciwu 
wobec tradycyjnych religii. $\mathrm{W}$ interpretacjach socjologicznych nowa duchowość pojawiła się w związku z krytyką teorii sekularyzacyjnych oraz badaniem nowych trendów kulturowych, dotyczących postępów indywidualizacji i autonomizacji jednostek, zwłaszcza wobec zinstytucjonalizowanych autorytetów (Pasek 2013: 37-38; Borowik, Mariański 2016; Kaczmarek 2019).

W socjologii współczesnej coraz bardziej upowszechnia się teza, że religie pozostają, ale zmieniają swoje kształty (retardacja procesów sekularyzacyjnych). Proklamowany przez niektórych socjologów powrót religii ma swoje różne postaci, przejawia się w różnych dziedzinach życia, bardziej jako zainteresowanie tematami religijnymi (np. w telewizji, internecie, reklamie, muzyce, w polityce) niż jako upowszechnianie się pewnego stylu życia dotyczącego zaspokajania potrzeb egzystencjalnych i transcendentnych, a już z pewnością nie w formie religijności kościelnej. Uświadamiany coraz bardziej i przeżywany pluralizm religijny sprzyja kształtowaniu się nowych tożsamości religijnych (duchowych), będących swoistym „skrzyżowaniem się” różnych idei religijnych i światopoglądowych. Rozwój nowych form religijności i duchowości prowadzi do zacierania granic między tym, co religijne i niereligijne. Płynność i rozmycie tych granic skłania innych do szukania pewności w ruchach fundamentalistycznych oferujących rzeczywiste lub rzekome bezpieczeństwo religijne (nowe formatowanie religijności). Coraz częściej, nawet w odniesieniu do Europy Zachodniej, mówi się o procesach desekularyzacyjnych. Obok dominującej jeszcze w wielu krajach religijności kościelnej, często selektywnej, niekonsekwentnej i sfragmentaryzowanej, ujawniają się różnorodne formy religijności pozakościelnej oraz nowej duchowości o charakterze synkretycznym.

Jeżeli wpływ Kościołów chrześcijańskich - przynajmniej w Europie Zachodniej - słabnie, to część ludzi usiłuje, jeśli nie traci wiary, zaspokajać swoje potrzeby religijne poza Kościołami, poszukuje poza nimi odpowiedzi na pytania i problemy religijne, rezygnuje $\mathrm{z}$ niektórych rytuałów religijno-kościelnych lub praktykuje z motywów pozareligijnych. Osłabienie Kościoła, jego pozycji w życiu społecznym i roli w życiu członków, może prowadzić do prywatyzacji religijności, która staje się sprawą wyboru i indywidualnej decyzji. Religijność pozakościelna jest ważnym segmentem religijności we współczesnych społeczeństwach.

Coraz częściej, nawet w odniesieniu do Europy Zachodniej, mówi się o procesach desekularyzacyjnych. Obok dominującej jeszcze w wielu krajach religijności kościelnej, często selektywnej, niekonsekwentnej, rozproszonej i sfragmentaryzowanej, ujawniają się różnorodne formy religijności pozakościelnej oraz nowej duchowości o charakterze synkretycznym. Nawet niektórzy zwolennicy tezy sekularyzacyjnej (np. socjolog niemiecki Detlef Pollack) wskazują na wzrost znaczenia w społeczeństwach współczesnych, także zsekularyzowanych, różnych form religijności alternatywnej. Nie rekompensuje to jednak $w$ pełni utraty znaczenia tradycyjnych form religijności (Pollack 2014). Jeżeli nawet Europa nie będzie chrześcijańska, to religie będą w niej zawsze obecne. Europa bez religii nie jest możliwa ani nie należy sobie tego życzyć. 
Ta rodząca się tendencja ku duchowości ma wiele wymiarów i kształtów, pojawia się z różną siłą w poszczególnych społeczeństwach. Sprzyja temu rozwijający się pluralizm społeczno-kulturowy i indywidualizm strukturalny, połączony z zakwestionowaniem, a nawet całkowitym odrzuceniem tradycyjnych autorytetów i norm. Zasługuje ona z pewnością na uważne studia badawcze, także z socjologicznego punktu widzenia. Duchowość stała się powszechną cechą nowoczesnych społeczeństw europejskich (Davie 2010: 222). Z tego też powodu studia nad duchowością zyskują na znaczeniu we współczesnej socjologii religii, zarówno na płaszczyźnie teoretycznej, jak i empirycznej, zwłaszcza w warunkach, gdy autorytety religijne tracą kontrolę nad wierzeniami, praktykami i zasadami moralnymi jednostek i grup społecznych. We współczesnych formach religijności i duchowości jest znacznie więcej tego, czego życzą sobie wierni, niż tego, czego oczekuje lub nawet żąda Kościół.

Bez wątpienia kategoria nowej duchowości poszerza pole badawcze dla socjologii, zarówno gdy chodzi o kulturę współczesną, jak i o religię. Prowadzi ona zarówno do transformacji społeczeństwa, jak i do przekształceń religii. Ponieważ wpływa ona bez wątpienia na życie społeczne, powinna stać się w większym stopniu przedmiotem badań socjologicznych. Kategoria duchowości nie powinna jednak eliminować z refleksji socjologicznej kategorię religijności. Nowa duchowość ze względu na swoją niedokładność i wieloznaczność jest bez wątpienia trudniejszym tematem badawczym niż religijność. Subiektywne i zindywidualizowane formy nowej duchowości upowszechniają się w ponowoczesnych społeczeństwach, występują do pewnego stopnia równolegle z kurczeniem się obszarów religii zinstytucjonalizowanych i tradycyjnych Kościołów chrześcijańskich, uprawniają do wylegitymizowania nowej subdyscypliny socjologicznej, tj. socjologii duchowości lub nawet uduchowionej socjologii czy socjologii duchowej, w każdym razie $\mathrm{z}$ pewnością nowego kierunku (nurtu) badań w ramach socjologii religii. Socjologia duchowości nie musi oznaczać jakiegoś „zaczarowania” socjologii.

Nowe formy niekościelnej (pozakościelnej) religijności i duchowości stają się coraz bardziej obecne w życiu codziennym wielu ludzi współczesnych. Nie mogą być traktowane jako zjawisko incydentalne, przejściowe, o marginalnym znaczeniu. Socjologia religii, także uprawiana w ośrodkach kościelnych, nie może tych indywidualnych i społecznych faktów ignorować, lecz powinno się poddawać je systematycznym badaniom empirycznym oraz pogłębionym wyjaśnieniom i interpretacjom. Zwłaszcza nowa duchowość stanowi ważne wyzwanie dla psychologów i socjologów i może stać się atrakcyjnym przedmiotem badań empirycznych. Duchowość staje się częścią składową kultur światowych.

Duchowość staje się jedną z ważnych cech współczesnych społeczeństw (ponowoczesnych), niezależnie od tego, czy będziemy ją traktować jako wyższą kulturowo inną formę religijności, czy też jako postchrześcijański poganizm. 
Duchowość odgrywa niewiarygodnie ważną rolę w naszej kulturze: poszerzając i wzbogacając ludzką podmiotowość; łącząc nas z szerszą rzeczywistością, w której jesteśmy osadzeni; ponownie nadając urok światu; odsłaniając to, co nieprawdopodobne w różnych wymiarach egzystencji; oraz wypełniając nasze życie tajemnicą, witalnością i zdumieniem. Świat pozbawiony ducha jest zubożały (Rubin 2009: 225).

Trzeba jednak zaznaczyć, że takie przejawy respirytualizacji, jak tęsknota za Bogiem, przeżywanie sacrum w różnych przejawach życia codziennego, poszukiwanie sensu życia, różne duchowe doznania itp., są niejednokrotnie lepiej zagospodarowane przez nowe ruchy religijne niż przez Kościoły chrześcijańskie. Do badania tych nowych trendów w przemianach religijnych i duchowych nie są już wystarczające konwencjonalne metody rozpoznania „,pola religijnego”.

Współczesne „miasto bez Boga” przekształca się w „miasto z wieloma bóstwami”. Religijność nie znika, lecz zmienia się, jest ambiwalentna, wielokształtna, do pewnego stopnia wszędobylska. Nie możemy być całkowicie pewni, że dalsze odrodzenie religijne nie nastąpi w kilku dekadach XXI w. Pytanie zaś, jaka będzie religijność w najbliższych dekadach XXI w., pozostaje bez uprawomocnionej odpowiedzi. Sekularyzacja, desekularyzacja i nowa duchowość opisują trzy trendy kulturowe, diagnozują - każdy na swój sposób - to, co dzieje się z religią w ponowoczesnym świecie. Pomimo tych wszystkich przemian religia zorientowana kościelnie jest wciąż obecna w życiu jednostek i społeczeństw, a w niektórych społeczeństwach, jak np. w Polsce, jest wciąż dominującą. Z kolei bezreligijne sacrum pojawia się i rozwija w tych dziedzinach, w których religia nie jest aktywna. Można by sobie życzyć, by Kościoły chrześcijańskie stawały się lepszym adresatem dla duchowych poszukiwaczy czy duchowych pielgrzymów.

Termin „nowa duchowość” często jest traktowany jako odrębny od religii, zwłaszcza od tradycyjnych religii. Zwrot ku duchowości nie tyle jest traktowany jako ewolucja dotychczasowych form religijności, lecz ich przeciwstawienie. Może on być jednak traktowany jako transformacja religii, która w nowych kształtach jest dobrze przystosowana do przekształcających się społeczeństw współczesnych. Część socjologów mówi w XXI w. o megatrendzie religia, inni o megatrendzie duchowość, inni zaś o megatrendzie niereligijność. Jedni wskazują na upadek religijnej tradycji, mówią o procesach sekularyzacyjnych, o „odkościelnieniu” i sekularyzmie, inni dostrzegają różnorodne przejawy powrotu religii, o respirytualizacji, o ponownym „oczarowaniu” czy o społeczeństwie postsekularnym. Dla niektórych socjologów rozwój nowych form religijności i duchowości jest przejawem tendencji desekularyzacyjnych we współczesnym świecie i zaprzeczeniem procesów sekularyzacyjnych.

Obydwie formy: religijność i duchowość nie muszą się sobie przeciwstawiać, wręcz przeciwnie i de facto często wzajemnie się przenikają, chociaż socjologowie chętnie te dwie rzeczywistości psychospołeczne oddzielają od siebie i traktują 
alternatywnie, umieszczając nową duchowość poza kontekstem religijnym. Nie jest to jednak separacja pełna. Ze względu na to, że nowa duchowość wykazuje wiele podobieństw do religijności pozainstytucjonalnej (pozakościelnej) nie wydaje się konieczne przeciwstawianie jej religijności, lecz raczej traktowanie jej jako poszerzenie czy dopełnienie dotychczasowych form i kształtów religijności (socjologia duchowości jako część socjologii religii). Kwestia ta nie jest jednoznacznie rozstrzygnięta.

\section{Cechy charakterystyczne nowej duchowości}

Nowa duchowość staje się jedną z wielu ważnych opcji do wyboru ludzi współczesnych, ale też wskazuje - przynajmniej pośrednio - że duchowość jest częścią integralną kondycji ludzkiej. W pluralistycznych i ponowoczesnych społeczeństwach ludzie poszukują sensu i orientacji w życiu, nawet jeżeli tracą kontakt $\mathrm{z}$ religiami tradycyjnymi, poszukują nowych form duchowości. Jeżeli religię określimy jako „system wierzeń i rytuałów dotyczących obszaru świętości” (Goodman 1997: 215), wówczas wiele form duchowości, także nowej duchowości, można byłoby określić jako bliskie religijności. Szerokie rozumienie religii nie osłabia dyskusji na temat różnych form duchowości. W ogóle w rozważaniach nad nową duchowością znajdujemy się jakby na śliskim lodzie, nie dochodzimy do satysfakcjonujących rozwiązań. Dla wielu ludzi współczesnych duchowość

bywa odnoszona do sposobu życia człowieka, w którym nie ma odniesień do Boga, co pozwala nazwać ją duchowością naturalną. Łączy się ją nie tylko z praktyką życia duchowego (sens subiektywny) i usystematyzowaną refleksją nad nim (sens obiektywny), ale też z praktyką życia bez odwoływania się do transcendencji - Boga (Marek, Walulik 2019: 114).

Niekiedy nową duchowość interpretuje się w kategoriach etycznych jako dążenie do pewnej doskonałości moralnej, która ukonkretnia się poprzez zasady moralne.

Tak rozumiana nowa duchowość staje się kategorią etyczną, która porządkuje zasady świeckie wskazujące istnienie wartości nadających sens życiu, które zachowują orientację na Transcendens mimo zakwestionowania wiary religijnej oraz dystansowania się od instytucji kościelnych (Mielicka-Pawłowska 2019: 16).

Jeżeli duchowość, w tym i nową duchowość, ujmujemy w perspektywie etycznej, wówczas jest ona realizacją istoty człowieczeństwa, pozwalającą dostrzec cele ludzkie, przede wszystkim cele dalekosiężne. Chodzi tu o wartości naczelne, uniwersalne, ogólnoludzkie, do osiągnięcia których dąży się świadomie, w sposób wolny, w dobrych relacjach z innymi (porozumienie, współdziałanie). Duchowość 
określana w kategoriach etycznych stanowi dla człowieka przestrzeń transcendencji własnej kondycji, kieruje go ku podmiotowości i autonomii, pozwalając w sposób wolny realizować wartości wyższe jako „dobre” wartości. Jeżeli rozwój duchowości nie jest skierowany na wartości naczelne, staje się on transgresją jedynie i w stronę wolności własnego „ja”, gubi wyraźny cel osobotwórczy i wspólnototwórczy (Olbrycht 2018). W konsekwencji można przyjąć określenie duchowości jako „podmiotowości zorientowanej w myśleniu, przeżywaniu i działaniu na przekraczanie natury, w celu świadomej, wolnej i odpowiedzialnej realizacji wartości absolutnych, uniwersalnych, ogólnoludzkich" (tamże: 79).

Badanie tak rozumianej duchowości można usytuować zarówno w ramach socjologii religii, jak i socjologii moralności. Socjologię duchowości, rozumianą jako część socjologii moralności, można zdefiniować jako naukę „o zdobywaniu doskonałości moralnej, charakterystycznej dla określonych grup społecznych, oraz o strukturach instytucjonalno-organizacyjnych wspierających dynamikę tego procesu, ze szczególnym uwzględnieniem szkół duchowości” (Jeżowski 2010: 77). Niezależnie od tego, czy socjologię duchowości będziemy traktować jako odrębną subdyscyplinę socjologiczną, czy jako część socjologii religii czy socjologii moralności, nie należy oczekiwać jej pełnej legitymizacji w najbliższej przyszłości jako nowej subdyscypliny socjologicznej. Zjawiska nowej duchowości i alternatywnej religijności nie powinny być przeceniane kosztem instytucjonalnych form religijności, które w dalszym ciągu są dominujące w wielu społeczeństwach współczesnych. Badanie tych dominujących tendencji rozwojowych powinno być naczelnym celem socjologii religii (Rogińska 2014).

Z wielu różnych ujęć nowej duchowości można wydobyć kilka wiodących treści, cech charakterystycznych i jej przejawów. Nie jest to łatwe, gdyż nowa duchowość wyraża się w różnych formach i treściach, a niemal dla każdego badacza oznacza coś innego. Duchowość obejmuje bardzo zróżnicowane treści: akceptację siebie, poszukiwanie sensu życia, umiejętność poświęcenia się dla osób i wartości, intensywne przeżywanie piękna, uznanie świętości natury, więź z ludźmi, naturą i kosmosem, doświadczenie medytacyjne, psychozmienną energię, więź z bóstwem itp. Można jednak próbować sformułować kilka cech charakterystycznych nowej duchowości powtarzających się w wielu definicjach tego zjawiska.

a) Nowa duchowość, która staje się swoistym megatrendem społeczno-kulturowym, ma swoje źródła w rozmaitych tradycjach religijnych i duchowych, zarówno w zachodniej tradycji ezoterycznej, jak i duchowości orientalnej, duchowości nawiązującej do religii przedchrześcijańskich, jak i pewnych elementów duchowości chrześcijańskiej. Jej źródeł należy poszukiwać zarówno w młodzieżowej kontrkulturze z końca XX w., jak i w New Age oraz w wielu innych źródłach, m.in. w pewnych cechach ponowoczesnej kultury i ponowoczesnych społeczeństw (Nowaczyk 2005; Nockiewicz 2016).

b) Duchowość i nowa duchowość wiążą się z procesami indywidualizacji, a poprzez swoją subiektywność stoją one bardzo często w opozycji (dystansie) wobec 
zinstytucjonalizowanych religii, które charakteryzują się sztywnymi strukturami i organizacją, dogmatami i rygorystycznymi normami oraz zinstytucjonalizowanymi rytuałami. Zaakcentowanie wymiaru subiektywności jest ważną cechą wyróżniającą nową duchowość od religijności, nawet jeżeli nie wyklucza to pewnych form wspólnotowości w nowej duchowości. Subiektywizacja oznacza zaakcentowanie idei rozwoju i samorozwoju, osobowego i wewnętrznego doskonalenia się. „Duchowość jest formą religijności pozainstytucjonalnej, zorientowanej na poszukiwanie kontaktu z sacrum, niezależnie od tego, jak ono jest wyobrażane. Zindywidualizowane pojęcie wiary prowadzi do sprywatyzowania sacrum" (Mielicka-Pawłowska 2013: 378-379).

c) Jeżeli nawet duchowość nie da się określić bez jakiegoś odniesienia do transcendencji, to jej konkretne formy nie muszą wyrażać się ani teistycznie, ani religijnie. Wiele form nowej duchowości można definiować jako duchowość postreligijną, a nawet jako duchowość bez Boga. Można tu już mówić o ostatecznej sekularyzacji świadomości religijnej. Nowa duchowość jest niekiedy przeciwstawiana temu, co religijne. Duchowość nie jest zdogmatyzowana, zinstytucjonalizowana, normatywna, związana z instytucjami kościelnymi, jest postawą z wyboru, w której indywidualne, wewnętrzne doświadczenie nabiera rangi ostatecznej instancji. Ma więc charakter inkluzywny, a nie ekskluzywny. Kościoły w tym kontekście jawią się jako przeszkoda do rozwoju osobowości. Duchowość jest zakotwiczona w wewnętrznym, subiektywnym świecie jednostki. Niektórzy uważają nawet, że odeszli od religii, aby rozwijać się duchowo.

d) Nowa duchowość jest określana najczęściej w opozycji do religii, a niekiedy nawet do sacrum, jest zdystansowana wobec wszelkiej dogmatyki religijnej, nie posiada publicznych reperkusji ani na ogół wspólnotowo celebrowanych rytuałów i kultów. Wiąże się ona na ogół z jakąś formą „małej transcendencji”, przekraczaniem biologicznej kondycji ludzkiej, z poszukiwaniem wartości niosących sens życia, dobrostanem psychicznym, pozytywnym stylem życia. Brak odniesień do religii nie oznacza braku odniesienia do jakiejkolwiek transcendencji, może być ona elementem życia każdego człowieka, bez względu na to, czy jest on religijny, czy niereligijny, a nawet ateistą. Nie oczekuje się „zbawienia” od Kościołów chrześcijańskich, a nawet szerzej - od religii, jest ono jakby sprawą jednostki i jej działań. Transcendentne czy boskie źródła duchowości i sensu odpowiedzialności etycznej przejmuje sam podmiot, co oznacza rozszerzenie świadomości „ja” współczesnego człowieka. Wielu ludzi skłania się do wierzenia, że sami mogą się zbawić, a nawet zbawić innych.

e) Nowa duchowość nie może być utożsamiana wyłącznie z nowymi ruchami religijnymi, czy New Age, stała się ona swoistym trendem czy megatrendem we współczesnym świecie. Jest niezwykle zmienna i zindywidualizowana, w której docenia się subiektywne doświadczenia i osobiste doznania. Zakwestionowanie opozycji sacrum-profanum sprawia, że sacrum przemieszcza się do tych sfer ludzkiego życia, w których było ono już nieobecne. W nowych ruchach religijnych 
i New Age urzeczywistnia się nowa duchowość. Nie zawsze można ją sterylnie oddzielić od jakichkolwiek powiązań z tradycjami religijnymi (Mariański 2010a: 19-34; Wójtowicz 2010; Wójtowicz, Klimski 2019).

f) Nowa duchowość ma związek z wartościami, które oznaczają rozwój duchowy, doskonalenie wewnętrzne, etyczny lub estetyczny wymiar ludzkiego „ja”, poczucie szczęścia i spełnienia w życiu, to ona sama określa, w co ma wierzyć. Ważne jest to, co stanowi dobro dla jednostki, co wiąże się z poszukiwaniem znaczenia i interpretacją życia. Otwartość na wartości oznacza ubogacenie ludzkiego życia. Wartości bowiem - przynajmniej pośrednio - wyznaczają to, do czego dążymy, i to, jak powinniśmy postępować. Nowa duchowość wskazuje na realne propozycje nowego stylu życia i poznania (nowa świadomość), prowadzącego do szczęścia i psychologicznego dobrostanu. Nie tyle jest ona fenomenem społecznym, ile raczej indywidualnym i osobistym, ale kształtuje się w określonym, złożonym kontekście społecznym, w społeczeństwie radykalnego pluralizmu i strukturalnego indywidualizmu (Obuchowski, Makary 2010).

g) Wiara religijna przekształca się w wiarę we własne „ja”, w samorealizację, w subiektywność, następuje przesunięcie od wspólnoty do jednostki i orientacja na immanentne wartości i cele. Duchowość wiąże się bardziej ze światem wewnętrznym jednostki, religijność ma bardziej odniesienia zewnętrzne. Do kontaktu z szeroko rozumianym sacrum nie jest konieczne członkostwo grupowe czy wspólnotowe. Jeżeli nawet powiązania nowej duchowości z wiarą religijną są niemal niewidoczne, to niekiedy wydaje się, że w niektórych jej formach jest jeszcze obecny „duch martwych wierzeń religijnych” (wyrażenie Maxa Webera).

h) Nowa duchowość wiąże się niejednokrotnie z poszukiwaniem i nadawaniem sensu zarówno codziennym doświadczeniom człowieka, jak i całej jego egzystencji. Zwana niekiedy duchowością pozareligijną odnosi się do tematów pozbawionych wymiaru religijnego, lecz służących jednostce jako narzędzia transcendowania, czyli usensowniającego przekraczania życia codziennego (Zwierżdżyński 2010). Sens życia jest dziełem i niemal wyłączną sprawą jednostki i tego, co zrobi ona ze swoim życiem. Przedmiotem określającym to, co duchowe, staje się konkretna jednostka (przejście od instytucjonalizacji do indywidualizacji). Poprzez rozwój sfery duchowej człowiek jest w stanie ukształtować dojrzałą postawę wobec siebie i wobec otaczającego go świata (Bałys 2011; Lulek, Głaz 2009), w ramach wolnego wyboru na zasadzie „zrób to sam”.

i) Nowa duchowość obejmuje zarówno jakieś ezoteryczne zagłębianie się w siebie, jak i troskę o dobre samopoczucie czy przyjemność (wellnes, fitness, selfness) (Jäger, Quarch 2007; Kubińska 2010), ale i poszukiwanie głębszych orientacji, związanych z sensem życia. Jest ona do pewnego stopnia zastępczą formą religii, jej „miękką” ofertą, mniej wymagającą, nastawioną na wzmocnienie „konsumenta”, pozbawioną rygorystycznych wymagań i wyzwań. Tak szeroko rozumiana duchowość nie daje się łatwo zoperacjonalizować $\mathrm{w}$ badaniach empirycznych, pozostaje ona wciąż jednym z najbardziej mglistych i nieokreślonych 
pojęć w socjologii (Pucko 2007). Sama duchowość nie jest „towarem” zastygłym, lecz wciąż zmieniającą się rzeczywistością, w której możliwość zmienia się w obowiązek (,jeżeli możesz coś zrobić, to musisz to zrobić”).

j) Duchowość niereligijna czy niemająca związku z religią jest więc w stanie nadać sens i cel życiu człowieka, spowodować, że osiągnie on poczucie szczęścia i satysfakcji z moralnie poprawnego przeżywania własnej egzystencji, w symbiozie z innymi ludźmi, bez odwoływania się do zasad jakiejś religii i norm etycznych przez nią wytwarzanych (Baniak 2013). Tak rozumiana duchowość jest do pewnego stopnia dostępna dla wszystkich, którzy poszukują głębszych wymiarów człowieczeństwa (swoista demokratyzacja sacrum) (Pace 2008), nawet jeżeli ich wyobrażenia o sacrum wykraczają daleko poza systemy wierzeń religijnych. Wyraża się to m.in. w dążeniu do wartości duchowych, które można określić jako „najbardziej podstawowe cele i dobra, które umożliwiają rozwój człowieka w tym, co w jego życiu jest najważniejsze i specyficznie ludzkie. Stąd podstawowe wartości duchowe to: miłość, prawda, odpowiedzialność, wolność, dobro, piękno, wiara, nadzieja, zbawienie" (Dziewiecki 2002: 33).

Jesteśmy dalecy od satysfakcjonującego określenia, czym jest nowa duchowość. Wiele definicji tego zjawiska sprawia wrażenie wersji roboczych. Niektórzy badacze społeczni w ogóle nie troszczą się o zdefiniowanie przedmiotu swoich poszukiwań naukowych, a nawet niekiedy świadomie tego unikają. Wielu nie wiąże nowej duchowości z religią lub co najwyżej z różnymi formami transcendencji. Można by powiedzieć, że poszukiwanie nowej duchowości jest jakimś kolejnym zwrotem w kierunku sacrum. Nowe sacrum religijne, czy tym bardziej niereligijne, jest bardzo płynne znaczeniowo i nieostre. Trudności teoretyczne i metodologiczne w precyzyjnym zdefiniowaniu nowej duchowości wynikają z szerokiego spektrum zjawisk, do których ten termin się odnosi (Pawluczuk 2010). Janusz Mariański i Stanisław A. Wargacki - w konsekwencji rozważeń nad nową duchowością jako megatrendem społeczno-kulturowym - zaproponowali następującą jej definicję:

Nowa duchowość to jeden z megatrendów początku XXI w., to doświadczenie sacrum, niekiedy bezimiennego, rozumianego $\mathrm{w}$ kategoriach czegoś osobistego, intymnego, czegoś co odnosi się do mocy tkwiącej we wnętrzu człowieka. Duchowość ta podkreśla rolę doznań i duchowych ćwiczeń, traktuje ludzkie ciało jako wypełnione wewnętrznym, duchowym sensem oraz jako manifestację kreatywnej siły Ducha; odnosi się z szacunkiem do natury i propaguje zdrowe odżywianie; przywiązuje dużą wagę do więzi międzyludzkich opartych na wierności i miłości; do etyki wyrażającej się w poszanowaniu uznawanych przez siebie wartości moralnych; jest wrażliwa na sztukę, podkreśla też równość płci. Duchowość ta jest holistyczna, demokratyczna, łatwo dostępna i nie hierarchiczna; stawiana jest ona w opozycji do zinstytucjonalizowanej religii, czyli jest pozakościelna (Mariański, Wargacki 2011: 138). 
Od samego początku problematyka nowej duchowości budzi w kręgach socjologów wiele kontrowersji i dyskusji, zarówno gdy chodzi o samą koncepcję nowej duchowości, jak i metodologię jej badań. Kształtujący się coraz wyraźniej „rynek duchowości" nie może być pomijany w badaniach socjologicznych. Ustawicznie przybywa ludzi, którzy definiują siebie jako „uduchowieni”, a nie „religijni”. Trzeba jednak krytycznie zaznaczyć, że pojęcie nowej duchowości obejmuje zbyt różnorodne treści, stanowi swoisty „worek” czy „kontener”, do którego wrzuca się niemal wszystko, co nie kojarzy się z tradycją religijną. Duchowość pozbawiona konkretnych form instytucjonalnych nie jest łatwa dla badań socjologicznych, jest ulotna jak fale morskie. Niemniej, jednostka i jej doświadczenia duchowe powinny znaleźć się w centrum zainteresowań psychologów, kulturoznawców, socjologów i przedstawicieli nauk pedagogicznych. Kategoria duchowości uzyskuje swój znaczący wymiar, który nie ma swojego zamiennika (Rembierz 2018).

Poszukiwanie nowej duchowości, swoisty powrót do sacrum, oznacza z jednej strony odejście od tradycyjnego, religijnego rozumienia sensu z jego odniesieniem do Wielkiej Transcendencji w znaczeniu Luckmannowskim, z drugiej strony jest zaakcentowaniem życia jako wartości samej w sobie, będącym źródłem poznawania siebie i rozwoju osobowego (doświadczenie wertykalne). W zróżnicowanych przejawach nowej duchowości akcentuje się przede wszystkim własne doświadczenie, autonomię (suwerenność) podmiotu i jego kompetencje, subiektywizację wiary, antydogmatyczność, niezależność od zinstytucjonalizowanych, przestarzałych struktur kościelnych, a niekiedy i antykościelność (wrogość wobec instytucji i autorytetów) (Berger 2007: 92; Susabowska 2013). Niekiedy duchowość rozumie się jako religijność bez skłaniania się ku żadnemu konkretnemu Kościołowi.

Nowa duchowość wyraża się w powiedzeniu: „nie jestem religijny, jestem duchowy”, ,jestem niereligijny, ale poszukuję duchowości”, duchowości, która jest już bardzo luźno związana z tradycyjnymi religiami, najczęściej nie jest już powiązana z wiarą w Boga jako pewien Absolut. W Europie Zachodniej około 15\% badanych wybiera określenie: „jestem niereligijny, ale duchowy”, w Polsce - około 2\% (Barker 2004). Czy z całą świadomością dokonują tego wyboru - tego nie wiemy, ale taki wskaźnik pojawił się także w naszym kraju. Obserwujemy powolny rozwój nowych form duchowości. Mają one często znamiona synkretyzmu i nawiązują do różnych nurtów psychologicznych, psychoterapeutycznych, ezoterycznych, magicznych czy paranormalnych.

O ile z trudem można sobie wyobrazić religijność bez jakiejś formy duchowości, o tyle dzisiaj coraz częściej spotykamy się z duchowością bez wyraźnych odniesień do religii. W nowej duchowości nie mamy do czynienia z podporządkowaniem się Bogu, lecz z procesem indywidualizacji, w centrum którego stoi poszukująca swojego „ja” jednostka i jej rozwój. Zindywidualizowana duchowość rozumiana jako poszukiwanie sensu i własnego szczęścia charakteryzuje się wysoką koniunkturą. Powoli do pewnego stopnia zastępuje zindywidualizowaną religijność. Ponowoczesna duchowość jest sprawą prywatną, ale jest ona też do pewnego 
stopnia produktem ponowoczesności i jej form zindywidualizowanego życia (Geisel 2006).

Z socjologicznego punktu widzenia należy traktować przejawy nowej duchowości bez uprzedzeń i potępień.

Przy tym wszystkim jednak należy zwrócić uwagę, by nie wylać dziecka z kąpielą. Niektórzy mianowicie uważają, że to, co się gdzieniegdzie zapowiada jako nową duchowość, z natury swojej pochodzi od diabła i powinno być odrzucone przez teologów. Moim natomiast zdaniem wszelkie poszukiwania duchowe, jako cecha człowieka, zasługuje na szacunek i uznanie. Poszukiwanie jest być może najsilniejszą formą Bożego działania w człowieku. Tylko ten, kto jest w drodze, może się zbliżyć także do Boga (Zulehner 2003: 30).

\section{Uwagi końcowe}

Przy końcu XX w. obok sekularyzacji i globalizacji jeszcze innym terminem, który pojawia się nad wyraz często w dyskursie naukowym, jest duchowość. Proklamuje się rewolucję duchową, która polega na przejściu od religii do duchowości i oznacza swoistą sakralizację nowoczesności czy ponowoczesności. Badacz zagadnienia duchowości w aspekcie historycznym Philip Sheldrake twierdzi wręcz, że duchowość jest słowem definiującym naszą erę. Wielu badaczy pisze też o „zwrocie ku duchowości" charakterystycznym dla przełomu wieków. W socjologii religii mówi się o pojawieniu się nowej subdyscypliny nazywanej socjologią duchowości, a brytyjski socjolog religii Kieran Flanagan podkreśla, że „duchowość, jako kategoria analityczna, nieoczekiwanie zawładnęła duszą socjologii” (Mariański, Wargacki 2011). Nowa duchowość pozwala być w jakimś stopniu „religijnymi” tym, którzy wyzwolili się od religii, czy przestali być wierzącymi chrześcijanami (Olbrycht 2018; Rembierz 2018; Mikołejko 2001), którzy nie odwołują się do zinstytucjonalizowanych norm i dogmatów religijnych (,jestem uduchowiony, ale tylko trochę religijny”; ,jestem osobą bardzo uduchowioną, ale niereligijną").

Obydwie formy: religijność i duchowość nie muszą się sobie przeciwstawiać, wręcz przeciwnie i de facto często wzajemnie się przenikają, chociaż socjologowie chętnie te dwie rzeczywistości psychospołeczne oddzielają od siebie i traktują alternatywnie, umieszczając nową duchowość poza kontekstem religijnym. Nie jest to jednak separacja pełna. Ze względu na to, że nowa duchowość wykazuje wiele podobieństw do religijności pozainstytucjonalnej (pozakościelnej), nie wydaje się konieczne przeciwstawianie jej religijności, lecz raczej traktowanie jej jako poszerzenie czy dopełnienie dotychczasowych form i kształtów religijności (socjologia duchowości jako część socjologii religii). Kwestia ta nie jest jednoznacznie rozstrzygnięta. 
Nowa religijność i nowa duchowość prowadzą do pewnych transformacji „pola religijnego", ale nie przekształcają je w sposób zasadniczy, do pewnego stopnia tworzy się nowe pole duchowości, bowiem nowa duchowość jest jakąś nowoczesną formą „wyznania religijnego”, nową formą transformacji życia ludzkiego. Bóg jako ktoś, komu przypisujemy prawo do stawiania wymagań i egzekwowania posłuszeństwa, powoli traci na znaczeniu w świadomości wielu ludzi współczesnych. Dokonuje się proces transformacji religijności kościelnej w pozakościelną i w niereligijną duchowość. Nie zawsze te nowe, wielopostaciowe formy religijności i duchowości są traktowane jako niepołączalne czy konfliktowe w odniesieniu do tradycyjnej religijności, niekiedy nawet są uznawane za komplementarne i kompatybilne. Nowe formy duchowości nie poddają się łatwo procesom instytucjonalizacji, podobnie jak nowe formy religijności rozproszonej (dyfuzyjnej) (Prüfer 2018), religijności nieoficjalnej czy niewidzialnej (Luckmann 1996).

Fakt, że coraz więcej ludzi używa dla określenia wyznawanej przez siebie wiary terminu „duchowość” zamiast „religijność” domaga się socjologicznego wyjaśnienia. Badania empiryczne nad duchowością wymagają z jednej strony wzmocnienia teoretycznego, z drugiej zaś stałego doskonalenia metod i technik badawczych. Z socjologicznego punktu widzenia pojęcie nowej duchowości ma charakter neutralny, opisuje jedynie cechy charakterystyczne tej indywidualnej orientacji wielu ludzi współczesnych. Dlatego też można mówić o pluralizmie różnych duchowości, także o pluralizmie nowych duchowości (Szauer 2015a, b).

Fenomen nowej duchowości wskazuje - przynajmniej pośrednio - że istnieje potrzeba jakiejś formy Transcendencji także w społeczeństwach, które wydawały się w znacznym stopniu zsekularyzowane. Warto w tym kontekście przytoczyć opinię abp. Józefa Życińskiego:

Jestem więc umiarkowanym optymistą i twierdzę, że zainteresowanie wartościami duchowymi będzie wzrastać, natomiast od przedstawicieli Kościoła instytucjonalnego będzie zależało, czy ludzie będą szukać zaspokojenia głodu duchowego w namiastkach typu New Age, czy też pragnienie to da się zaspokoić u najczystszego źródła (Życiński za: Zańko, Gowin 1998: 260).

Socjologia powinna w większym zakresie jak dotychczas zająć się zarówno badaniem duchowości zawierającej się w religijności, jak i duchowością istniejącą poza religią.

Paradoks polega na tym, że te osoby, które uważają się za niereligijne, nie stają się automatycznie ateistami. Coraz częściej zamiast o religijności mówi się o duchowości, na którą składają się nie tylko elementy jakiejś religijności, ale i psychologii i psychoterapii oraz alternatywnych form religijności. Wiara w jakąś moc i energię nieosobową zajmuje miejsce wiary w Boga osobowego. Tworzy się tożsamość transreligijna, duchowość niereligijna, duchowość agnostyczna, duchowość 
alternatywna, duchowość transgresyjna. Nowa duchowość ma przede wszystkim charakter zindywidualizowany, doświadczeniowy i subiektywistyczny, nie jest określana przez odniesienie do zinstytucjonalizowanej religijności. Taka duchowość pozbawiona teologicznych treści ma tendencję sakralizowania tego, co świeckie. Tworzą się nowe „pola” czy „sceny” religijności i nowej duchowości. Dla tych, którzy akceptują duchowość jako coś pozytywnego, religijność jawi się jako coś negatywnego. Duchowość mogą akceptować i często akceptują także niewierzący. Byłaby ona więc swoistym pomostem między wierzącymi i niewierzącymi (Wysocka 2019).

\section{Bibliografia}

Bałys M. (2011) Poczucie sensu życia a duchowość. Próba analizy koncepcji Viktora E. Frankla w: Etyka i sens życia, D. Probucka (red.), Kraków, Wydawnictwo Naukowe Uniwersytetu Pedagogicznego, s. 129-137.

Baniak J. (2013) Wielowymiarowość i konteksty kulturowe duchowości religijnej a inne formy duchowości, „Humaniora. Czasopismo Internetowe”, nr 2, s. 13-37.

Bańka J. (2012) Kultura duchowa jako istota kultury humanistycznej w: Filozofia Marii Szyszkowskiej. Księga dedykowana, A. Kryniecka (red.), Białystok, Kresowa Agencja Wydawnicza, s. 398-409.

Barker E. (2004) The Church without and the God Within: Religiosity and/or Spirituality? w: Religion and Patterns of Social, D. Marinović-Jerolimov, S. Zrinščak, I. Borowik (red.), Zagreb, Transformation. Ed. Institute for Social Research - ISORECEA, s. 36-37.

Berger P.L. (2007) Pytania o wiarę. Sceptyczna zachęta do chrześcijaństwa, tłum. J. Łoziński, Warszawa, Instytut Wydawniczy Pax.

Borowik I. (2016) Przemiany religijne $w$ Polsce na tle transformacji w Europie Środkowo-Wschodniej i globalizacji w: Globalny i lokalny wymiar religii. Polska w kontekście europejskim, I. Borowik, A. Górny, W. Świątkiewicz (red.), Kraków, Zakład Wydawniczy NOMOS, Uniwersytet Śląski w Katowicach, s. 7-16.

Borowik I., Mariański J. (2016) Religijność i duchowość w Polsce okresu transformacji - konflikt czy kontynuacja? w: Wobec zmian jutra. Co myślq Polacy i jak działają?, W. Morawski (red.), Warszawa, Wolters Kluwer, s. 423-449.

Chmielewski M. (2005) Duc in altum, Refleksje o życiu duchowym wygłoszone w Radio Maryja i TV TRWAM (2 I 2003-30 XII 2004), Częstochowa, Edycja Świętego Pawła.

Chmielewski M. (2013) Duchowość według Jana Pawła II. Studium na podstawie encyklik i adhortacji, Lublin, Wydawca: Polskie Stowarzyszenie Teologów Duchowości. 
Chmielewski M. (2017-2018) Współczesna polska teologia duchowości, „Duchowość w Polsce", nr 19-20, s. 191-217.

Chmielewski M. (2020) Św. Jan Paweł II o katolickiej duchowości, „Przegląd Uniwersytecki”, nr 2-3, s. 26-29.

Davie G. (2010) Socjologia religii, tłum. R. Babińska, Kraków, Zakład Wydawniczy NOMOS.

Dienberg von T., Thomas Eggensperger T., Engel U., (red.) (2013) Säkulare Frömmigkeit. Theologische Beiträge zu Säkularisierung und Individualisierung, Münster, Aschendorff Verlag.

Dobbelaere K. (2008) Sekularyzacja. Trzy poziomy analizy, tłum. R. Babińska, Kraków, Zakład Wydawniczy NOMOS.

Dziewięcki M. (2002) Wychowanie w dobie ponowoczesności, Kielce, Wydawnictwo JEDNOŚĆ.

Fedele A. (2020) La spiritualité comme terrain d'entente entre la religion et le sécularisme: une approche ethnographique, „Social Compass”, $\mathrm{nr}$ 2, s. 177-190.

Ferdek B. (2017) Duchowość jako interioryzacja dogmatu., „Studia Gnesnensia”, nr 31, s. $19-31$.

Geisel S. (2006) Neue Spiritualitäten w: Glaubenssache. Ein Buch für Gläubige und Ungläubige, von Stapferhaus Lenzburg (red.), Baden, Hier+jetzt, s. 140-143.

Goodman N. (1997) Wstęp do socjologii, tłum. J. Polak, J. Ruszkowski, U. Zielińska, Poznań, Wydawnictwo Zysk i S-ka.

Grabowska M. (2018) Bóg a sprawa polska. Poza granicami teorii sekularyzacji, Warszawa, Wydawnictwo Naukowe Scholar.

Haffner P. (2019) Bauman. Czynić swojskie obcym. Rozmowy Petera Haffnera z Zygmuntem Baumanem, tłum. K. Leszczyńska, Warszawa, Wydawnictwo: Wielka Litera.

Jäger W., Quarch Ch. (2007) Fitness, wellnes a duchowość, tłum. Z. Mazurek, Warszawa, Jacek Santorski \& Co Agencja Wydawnicza.

Jeżowski M. (2010) Duchowość - Paradygmat socjologii religii czy socjologii moralności? A może socjologia duchowości w: Religijność i duchowość - dawne i nowe formy, M. Libiszowska-Żółtkowska, S. Grotowska (red.), Kraków, Zakład Wydawniczy NOMOS, s. 66-78. 
Kaczmarek A. (2006) Charles Taylor wobec odwagi duchowości w: Fenomen duchowości, A. Grzegorczyk, J. Sójka, R. Koschany (red.), Poznań, Wydawnictwo Naukowe UAM, s. 225-233.

Kaczmarek J. (2019) Postsekularyzm - mikro- czy megatrend?, „Przegląd Religioznawczy", nr 4, s. 35-46.

Knoblauch H. (2005) Einleitung: Soziologie der Spiritualität, „Zeitschrift für Religionswissenschaft" 13, nr 2, s. 123-131.

Knoblauch H. (2006) Soziologie der Spiritualität w: Handbuch Spiritualität. Zugänge, Traditionen, interreligiöse Prozesse, K. von Baier (red .), Darmstadt, Wissenschaftliche Buchgesellschaft, s. 91-104.

Knoblauch H. (2008) Spirituality and Popular Religion in Europe, „Social Compass”, nr 2, s. 140-153.

Knoblauch H. (2009) Populäre Religion. Auf dem Weg in eine spirituelle Geselschaft, Frankfurt am Main, Campus Verlag.

Kojder A. (2009) Anegdoty, limeryki, epifanie. O socjologii i socjologiach, Warszawa, Oficyna Naukowa.

Kubińska J. (2010) Socjologiczno-aksjologiczny wymiar aktywności sportowej na przykładzie fitness w: Wartości - interesy - struktury społeczne. Uwarunkowania ludzkiej kreatywności i partycypacji w życiu publicznym, J. Szymczyk (red.), Lublin, Norbertinum, s. 155-172.

Kula L. (2012) Nowa droga ateizmu według André Comte’a-Sponville’a, „Zeszyty Naukowe Towarzystwa Doktorantów UJ Nauki Humanistyczne”, nr 4, s. 25-32.

Kutyło Ł. (2012a) Duchowe oazy na europejskiej „pustyni religijnej”?, „Kultura i Społeczeństwo" 56, nr 4, s. 197-201.

Kutyło Ł. (2012b) Teorie socjologiczne a religia. Między sekularyzacją a desekularyzacja, Łódź, Wydawnictwo Uniwersytetu Łódzkiego.

Libiszowska-Żółtkowska M. (2018) Resakralizacja w ponowoczesnej scenerii. Nowe odsłony religii i duchowości w: Religia wobec wyzwań współczesności z perspektywy nauk społecznych, I. Borowik, S. Grotowska, P. Piotr Stawiński (red.), Warszawa, Wydawnictwo Naukowe Scholar, s. 195-212.

Lowen A. (1994) Duchowość ciała, tłum. S. Sikora, Warszawa, Wydawnictwo Jacek Santorski \& Co. 
Luckmann T. (1996) Niewidzialna religia. Problem religii we współczesnym społeczeństwie, tłum. L. Bluszcz, Kraków, Zakład Wydawniczy NOMOS.

Lulek J., Głaz S. (2009) Problematyka sensu ludzkiego życia w: Człowiek i jego życie religijne, S. Głaz (red.), Kraków, Wydawnictwo WAM, s. 11-49.

Machniak J. (1999) Teologia duchowości. Stan aktualny i perspektywy rozwoju w: Duchowość chrześcijańska na progu trzeciego tysiąclecia. Księga Pamiątkowa ku czci Ojca Profesora Dominika Widera OCD, J. Machniak, J. W. Gogol (red.), Kraków, Wydawnictwo Naukowe Papieskiej Akademii Teologicznej, Wydawnictwo Karmelitów Bosych, s. $139-164$.

Marek Z., Walulik A. (2019) Pedagogika świadectwa. Perspektywa antropologiczno-kerygmatyczna, Kraków, Wydawnictwo Naukowe Akademii Ignatianum w Krakowie.

Mariański J. (2010a) Nowa duchowość - alternatywa czy dopełnienie religijności? w: Religijność i duchowość - dawne i nowe formy, M. Libiszowska-Żółtkowska, S. Grotowska (red.), Kraków, Zakład Wydawniczy NOMOS, s. 19-34.

Mariański J. (2010b) Religia w społeczeństwie ponowoczesnym, Warszawa, Oficyna Naukowa.

Mariański J. (2018) Duchowość religijna i niereligijna - analiza pojęć w: Religia wobec wyzwań współczesności z perspektywy nauk społecznych, I. Borowik, S. Grotowska, P. Stawiński (red.), Warszawa, Wydawnictwo Naukowe Scholar, s. 175-193.

Mariański J. (2019) Nowa religijność i duchowość - mit czy rzeczywistość? Studium socjologiczne, Warszawa, Warszawskie Wydawnictwo Socjologiczne.

Mariański J., Wargacki S. A. (2011) Nowa duchowość jako megatrend społeczny i kulturowy, „Przegląd Religioznawczy”, nr 4, s. 127-149.

Mariański J., Wargacki S.A. (2016) Płynne sacrum w społeczeństwie ponowoczesnym, „Uniwersyteckie Czasopismo Socjologiczne”, nr 4, s. 7-27.

McGuire M. B. (2012) Religia w kontekście społecznym, tłum. S. Bardziej, Kraków, Zakład Wydawniczy NOMOS.

Mielicka-Pawłowska H. (2013) Religijność zorientowana ekologicznie w: Religijne wymiary życia społecznego, H. Mielicka-Pawłowska (red.), Kielce, Wydawnictwo Uniwersytetu Jana Kochanowskiego w Kielcach, s. 376-394.

Mielicka-Pawłowska H. (2017a) Jak immanencja może stać się transcendencją? Rozważania o nowej duchowości w: Kościoły, religie, kultury. Współczesne wymiary reprezentacji i partycypacji, M. Sroczyńska, S. H. Zaręba (red.), Warszawa, Wydawnictwo Naukowe UKSW, s. 199-210. 
Mielicka-Pawłowska H. (2017b) Duchowość jako forma konstruowania porzq̨dku aksjonormatywnego, „Uniwersyteckie Czasopismo Socjologiczne”, nr 4, s. 67-74.

Mielicka-Pawłowska H. (2018) Wydarzenia religijne jako forma ponowoczesnej duchowości w: Religia wobec wyzwań współczesności z perspektywy nauk społecznych, I. Borowik, S. Grotowska, P. Stawiński (red.), Warszawa, Wydawnictwo Naukowe Scholar, s. 213-229.

Mielicka-Pawłowska H. (2019) Mit nowej religijności i duchowości w: J. Mariański Nowa religijność i duchowość - mit czy rzeczywistość? Studium socjologiczne, Warszawa, Warszawskie Wydawnictwo Socjologiczne.

Mikołejko Z. (2001) Katolicyzm polski pod presjq nowej duchowości w: Katolicyzm polski na przełomie wieków. Mity, rzeczywistość, obawy, nadzieje, J. Baniak (red.), Poznań, Uniwersytet im. Adama Mickiewicza Wydział Teologiczny - Redakcja Wydawnictw, s. 13-25.

Misztal W. (2017) Arcybiskupa Życińskiego koncepcja związków między duchowościq chrześcijańskq a mediami (przyczynek do badań) w: Media - kultura - dialog. W piq̨ta rocznicę śmierci arcybiskupa Józefa Życińskiego, R. Nęcek, W. Misztal (red.), Kraków, Uniwersytet Papieski Jana Pawła II w Krakowie, Wydawnictwo Naukowe. s. 53-74.

Motak D. (2010) Religia - religijność - duchowość. Przemiany zjawiska i ewolucja pojęcia, „Zeszyty Naukowe Uniwersytetu Jagiellońskiego. Studia Religiologica”, nr 43, s. 201-218.

Niedałtowski K. (2008) Duchowość ponowoczesna: wyzwania i aberracje w: Godność czy sukces? Kulturowe dylematy współczesności. Materiały III Kongresu Kultury Chrześcijańskiej. Katolicki Uniwersytet Lubelski Jana Pawła II Lublin, 25-28 września 2008 r., J. Mariański, S. Zięba (red.), Lublin, Towarzystwo Naukowe KUL, s. 167-177.

Nockiewicz I. (2016) Świadectwo chrześcijańskiej rodziny jako odpowiedź na problemy nowej indywidualistycznej duchowości, „Studia Teologiczne. Idźcie i Głoście”, nr 34, s. 95-97.

Nowaczyk M. (2005) Antynomie nowej duchowości w: Sekty czy nowe ruchy religijne. Wybrane zagadnienia, Z. Stachowski (red.), Tyczyn, Wydawca: Wyższa Szkoła Społeczno-Gospodarcza w Tyczynie, s. 41-58.

Obuchowski K., Stasiak M.K. (red.) (2010) Duchowy wymiar istnienia, Łódź, Wydawnictwo Akademii Historyczno-Ekonomicznej w Łodzi.

Ojciec Święty Franciszek (2013) Adhortacja apostolska Ewangelii Gaudium. O głoszeniu Ewangelii w dzisiejszym świecie, Kraków, Wydawnictwo M. 
Olbrycht K. (2018) Edukacyjne wymiary wspierania rozwoju duchowości człowieka, „Edukacja Międzykulturowa”, nr 2, s. 79-89.

Pace E. (2008) Poza porządkiem. Duchowość i system wiary w New Age, tłum. K. Suwada w: Nowa duchowość w społeczeństwach monokulturowych i pluralistycznych, K. Leszczyńska, Z. Pasek (red.), Kraków, Zakład Wydawniczy NOMOS, s. 22-29.

Pasek Z. (2008) Od religijności ku duchowości. Przyczynek do przemian kultury współczesnej w: Idee i Myśliciele. Filozoficzne i kulturoznawcze rozważania o duchowości i komunikowaniu, I.S. Fiut (red.), Kraków, Wydawnictwo AGH, s. 13-26.

Pasek Z. (2010) O przydatności pojęcia duchowość do badań nad współczesna kultura w: Religijność i duchowość - dawne i nowe formy, M. Libiszowska-Żółtkowska, S. Grotowska (red.), Kraków, Zakład Wydawniczy NOMOS, s. 56-65.

Pasek Z. (2013) Nowa duchowość. Konteksty kulturowe, Kraków, Wydawnictwo Aureus.

Pasek Z., Skowronek K. (2011) Duchowość jako kategoria analizy kulturoznawczej w: Kultura jako kultura, K. Łukasiewicz, I. Topp (red.), Wrocław, Wydawnictwo Uniwersytetu Wrocławskiego, s. 69-83.

Pawluczuk W. (2010) O pojęciu wiary w: $W$ poszukiwaniu sensu. $O$ religii, moralności i społeczeństwie, J. Baniak (red.), Kraków, Zakład Wydawniczy NOMOS, s. 29-38.

Pawluczuk W. (2016) Światopogląd a sposób bycia, Kraków, Wydawnictwo AVALON.

Pollack D. (2014) Religiöser Wandel in Ost- und Westeuropa: Soziologische Beschreibung und Erklärungen w: Europa mit oder ohne Religion? Der Beitrag der Religion zum gegenwärtigen und künftigen Europa, K. von Appel, I. Guanzini, A. Walser (red.) Göttingen, V \& R unipress, s. 93-120.

Prüfer P. (2018) Natura i struktura teorii religione diffusa Roberto Ciprianiego - osobliwość kontekstu, uniwersalizm koncepcji, „Humanistyka i Przyrodoznawstwo”, nr 24, s. 177-192.

Ptaszek R. T. (2015) Dlaczego nowa duchowość nie może być realnq alternatywa dla tradycyjnej religii?, „Paedagogia Christiana”, nr 1, s. 113-126.

Rembierz M. (2018) Edukacja międzykulturowa jako ćwiczenie duchowe. Pedagogiczne wymiary kształtowania kultury duchowej i rozumienia wartości ponadkulturowych w kontekście zróżnicowania religijnego i pluralizmu światopoglądowego, „Edukacja Międzykulturowa", nr 2, s. 90-130.

Rogińska M. (2014) Sacrum ponowoczesne. Nauka i nowa duchowość w poszukiwaniu całości, „Annales Universitatis Paedagogicae Cracoviensis. Studia Sociologica”, nr 1, s. 51-68. 
Romanowicz W. (2017) Nowa duchowość jako zjawisko społeczno-kulturowe w nowoczesnym społeczeństwie, „Rozprawy Społeczne”, nr 3, s. 7-13.

Rubin J. B. (2009) Psychoanaliza i duchowość, w: Psychoanaliza i religia w XXI wieku, D. M. Black (red.), tłum. A. Skórzak, Kraków, Wydawnictwo WAM, s. 203-230.

Sakowicz E. (2001) Duchowość małżeńska, „Homo Dei. Przegląd Teologiczno-Duszpasterski", nr 3, s. 56-61.

Sakowicz E. (2002) Duchowość dialogu międzyreligijnego w: Duchowość współczesnego Kościoła. Materiały z sympozjum z racji 185 rocznicy Wydziału Teologicznego, S. Urbański (red.), Warszawa, Wydawnictwo Uniwersytetu Kardynała Stefana Wyszyńskiego, s. 39-52.

Skowronek K., Pasek Z. (2013) Wstęp. Czy istnieje duchowość bez sacrum? Kilka słów o duchowości niereligujnej w: Pozareligijne wymiary duchowości, Z. Pasek, K. Skowronek, R. Tyrała (red.), Kraków, Wydawnictwo Libron, s. 7-16.

Sokołowska J. (2012) Duchowość w zarządzaniu - wybrane zagadnienia, „Annales. Etyka w życiu gospodarczym", nr 15, s. 347-353.

Solecki R., Borda M. (2018) Duchowość Chrześcijańska w procesie wychowania, Kraków, Wydawnictwo Naukowe Uniwersytet Papieski Jana Pawła II.

Stachowska E. (2019a) Światowe Dni Młodzieży w Krakowie w perspektywie socjologii religii, Kraków, Zakład Wydawniczy NOMOS.

Stachowska E. (2019b) Mobilizacje religijne w Polsce. Ujęcie socjologiczne, „Przegląd Religioznawczy", nr 4, s. 175-203.

Susabowska K. (2013) Duchowość pogranicza między Kościołem a sekta, czyli o próbie klasyfikacji zjawiska, „Zeszyty Naukowe Politechniki Śląskiej”, nr 65, s. 405-412.

Szauer R. (2015a) Rola i miejsce duchowości wśród uczestników diecezjalnego spotkania młodych w Skrzatuszu, „Rocznik Skrzatuski”, s. 41-56.

Szauer R. (2015b) Hala sportowa jako nowe Jeruzalem. Socjologiczne ujęcie zjawiska spotkań religijnych w przestrzeniach hal widowiskowo-sportowych, „Humaniora. Czasopismo Internetowe", nr 2, s. 47-63.

Sztaba M. (2014) Zagadnienie duchowości i religijności w integralnym wychowaniu osoby w: Wychowanie integralne w edukacji katolickiej. Idee - twórcy - instytucje, M. Loyola Opiela, E. Świdrak, M. Łobacz (red.), Lublin, Wydawnictwo Katolickiego Uniwersytetu Lubelskiego, s. 61-85. 
Taylor Ch. (2012) Glauben in einer säkularen Zeitalter. Formen religiösen Lebens, „Zur Debatte", nr 3, s. 17-18.

Tyrała R. (2013) Pozareligijna duchowość (polskich) niewierzących, „Studia Humanistyczne AGH", nr 3, s. 67-79.

Wargacki S. A. (2011) Współczesny człowiek i sacrum, „Misje Dzisiaj” (marzeckwiecień), s. 3-4.

Wargacki S. A. (2016) Duchowość w kulturze ponowoczesnej, „Zeszyty Naukowe KUL”, nr 4, s. 27-51.

Wójtowicz A. (2010) Duchowość czy kolonizacja religii w: Religijność i duchowość - dawne i nowe formy, M. Libiszowska-Żółtkowska, S. Grotowska (red.), Kraków, Zakład Wydawniczy NOMOS, s. 35-44.

Wójtowicz A., Klimski W. (red.) (2019) Pluralizm religijny i odmiany ezoteryzmu, Warszawa, Wydawnictwo Uniwersytetu Kardynała Stefana Wyszyńskiego w Warszawie.

Wysocka E. (2019) Religijność młodzieży studenckiej - przypisywane religii znaczenia w życiu codziennym (dwie dekady zmian), „Przegląd Religioznawczy”, nr 4, s. 105-120.

Zańko D., Gowin J. (1998) Niewidzialne światło. Z abp. Józefem Życińskim rozmawiaja Dorota Zańko i Jarosław Gowin, Kraków, Społeczny Instytut Wydawniczy Znak.

Zduniak A. (2016) Duchowość w epoce mediów elektronicznych w: Media i religia. Nowy kontekst komunikacji, R. Sierocki, M. Sokołowski, A. Zduniak (red.), Toruń, Wydawnictwo Adam Marszałek, s. 61-73.

Zduniak A. (2018) Event $w$ życiu społecznym i religijnym. Perspektywa socjologiczna, Olsztyn, Wydawnictwo Uniwersytetu Warmińsko-Mazurskiego w Olsztynie.

Zulehner P. M. (2003) Religia jako megatrend, „Keryks. Międzynarodowy Przegląd Katechetyczno-Pedagogicznoreligijny", nr 1, s. 21-35.

Zwierżdżyński M. K. (2010) Religia, duchowość, postmodenizm. Problem znaczeń w: Religijność i duchowość - dawne i nowe formy, M. Libiszowska-Żółtkowska, S. Grotowska (red.), Kraków, Zakład Wydawniczy NOMOS, s. 79-93. 